\title{
North-Eastern Russia and Moscow in the Annals of Poland by Jan Dlugosz
}

\author{
R. A. Nalivaiko
}

For citation: Nalivaiko R.A. North-Eastern Russia and Moscow in the Annals of Poland by Jan Dlugosz. Vestnik of Saint Petersburg University. History, 2020, vol. 65, iss. 1, pp. 49-60.

https://doi.org/10.21638/11701/spbu02.2020.103

The article analyzes the information dedicated to north-eastern Russia and Moscow contained in the "Annals of Poland" by Polish chronicler and historian Jan Dlugosz written in 1455-1480. The author notes that J.Dlugosz was the first Polish chronicler who used Russian and Russian-Lithuanian Chronicles and described the history of those Russian lands that became part of Poland and the Grand Duchy of Lithuania. J. Dlugosz created his historical work during the final stage of unification of the lands of North-Eastern Russia by Moscow, the struggle with the dependence on the Horde, but he didn't see either the completion of this process or the time when Lithuania began to lose Russian lands. The author notes the ambivalent attitude of J. Dlugosz to Moscow: on the one hand, the underestimation of the situation in the East, on the other - understanding of the emergence of a dangerous competitor. J. Dlugosz doesn't mention any Princes of Moscow of the $14^{\text {th }}$ century. Occasional references to Moscow and its rulers begin with Vasily I, but only in connection with Polish-Lithuanian affairs. Vasily II is not mentioned by name, although his activities are reflected in the Annals. Based on the fact that J.Dlugosz in one of the last reports of the Annals stating the strengthening position of Moscow under Ivan III gives him a laudatory characteristic, the author comes to the conclusion about the beginning of a gradual transformation of the image of Moscow from insignificant to threatening. Thus, J. Dlugosz notes the importance of the annexation of Novgorod and predicts future problems for Lithuania and Poland.

Keywords: Jan Dlugosz, Annals of Poland, Grand Duchy of Lithuania, Vasily I Dmitrievich, Ivan III, North-Eastern Russia, the rise of Moscow.

\section{Северо-Восточная Русь и Москва в Анналах Польши Яна Длугоша}

\section{Р. А. Наливайко}

Для цитирования: Nalivaiko R. A. North-Eastern Russia and Moscow in the Annals of Poland by Jan Dlugosz // Вестник Санкт-Петербургского университета. История. 2020. Т. 65. Вып. 1. С. 49-60. https://doi.org/10.21638/11701/spbu02.2020.103

В статье анализируется информация, посвященная Северо-Восточной Руси и Москве, содержащаяся в «Анналах Польши» польского хрониста и историка Яна Длугоша, на-

Roman A. Nalivaiko - PhD in History, Associate Professor, St. Petersburg State University, 7-9, Universitetskaia nab., St. Petersburg, 199034, Russian Federation; r.nalivaiko@spbu.ru

Роман Алексеевич Наливайко - канд. ист. наук, доцент, Санкт-Петербургский государственный университет, Российская Федерация, 199034, Санкт-Петербург, Университетская наб., 7-9; r.nalivaiko@spbu.ru

(C) Санкт-Петербургский государственный университет, 2020 
писанных в 1455-1480 гг. Автор отмечает, что Я.Длугош был первым из польских хронистов, который использовал русские и русско-литовские летописи и достаточно подробно описал историю тех русских земель, которые в итоге оказались в составе Польши и Великого княжества Литовского. При этом Я. Длугош создавал свое историческое произведение в период возвышения Москвы, завершающего этапа объединения ею земель Северо-Восточной Руси, борьбы с ордынской зависимостью, но завершения этого процесса не застал, как не застал и времени, когда Московское государство начало наступление, а Литва начала терять русские земли. Анализируя немногочисленные известия «Анналов», посвященные Северо-Восточной Руси, автор отмечает двойственное отношение Я. Длугоша к Москве. С одной стороны, недооценка положения на Востоке, с другой - понимание того, что появился опасный конкурент. В статье подчеркивается, что Я.Длугош не упоминает ни одного московского князя XIV в., ничего не пишет об истории Северо-Восточной Руси. Эпизодические упоминания Москвы и ее правителей начинаются с Василия I, причем только в связи с польско-литовскими делами, Василий II по имени не упомянут ни разу, хотя его деятельность отражена в «Анналах». На основе того факта, что Я.Длугош в одном из последних известий «Анналов», констатируя факт усиления Москвы при Иване III, дает ему хвалебную характеристику, автор приходит к выводу о начале постепенной трансформации образа Москвы от незначительного до представляющего угрозу. Так, Я. Длугош отмечает важность присоединения Новгорода и предрекает будущие проблемы для Литвы и Польши.

Ключевые слова: Ян Длугош, Анналь Польши, Великое княжество Литовское, Василий I Дмитриевич, Иван III, Северо-Восточная Русь, возвышение Москвы.

"Annales Poloniae" or "Annals of Poland" were written by the Polish chronicler Jan Dlugosz in $1455-1480$. In the $17^{\text {th }}-19^{\text {th }}$ centuries his historical work was published under the title "Historia Polonica". J. Dlugosz called his work "annals" in the introduction ${ }^{1}$ and in the epilogue 2 , and in the epilogue there is another title - "chronica" ${ }^{3}$. The autograph of the Annals doesn't have a title, but on the $18^{\text {th }}$-century binding there is the inscription: "Annales Poloniae Ioa. Dlugosch ad annum 1406. Autographum" 4 . This title "Annales Poloniae" (Annals of Poland) was used in the last Polish edition of the Latin text.

J.Dlugosz died on May 19, 1480; so he didn't know about "the Great Stand on the Ugra river", but he witnessed the annexation of Veliky Novgorod to Moscow, and already considered Moscow to be free from its dependency on the Horde. Also, J. Dlugosz did not live a few years to see the first Muscovite-Lithuanian border war, after which the Grand Duchy of Lithuania began to rapidly lose Russian lands, although he managed to express specific prophecies on this occasion. Therefore, it is especially interesting to analyze the information of Annals devoted to north-eastern Russia, which was being consolidated under the rule of Moscow at the time. Also, it is important to determine what information we can get from the Annals and to find out what sources J.Dlugosz used.

J.Dlugosz, unlike his predecessors, the Polish chroniclers Vincent Kadlubek, Gallus Anonymous and Jan of Czarnkow, describing the history of the neighboring states, from the legendary Kij and migrations of the Slavs until the late $13^{\text {th }}$ century, used not only Pol-

${ }^{1}$ Ioannis Długossii Annales seu Cronicae incliti Regni Poloniae. Varsaviae, 1964. Lib. I-II. P. 63.

2 Ioannis Długossii Annales seu Cronicae incliti Regni Poloniae. Varsaviae, 2005. Lib. XII (14621480). P. 445.

3 Ibid. P. 447.

${ }^{4}$ Dąbrowski J. Dawne dziejopisarstwo polskie (do roku 1480). Wrocław; Warszawa; Kraków, 1964. P.215; Semkowicz-Zarembina W. Powstanie i dzieje autografu Annalium Jana Długosza. Kraków, 1952. P. 6. 
ish, but also Russian and Russian-Lithuanian sources. The latest entry called "Russian" is the story about the poisoning of the rivers by the Tatars after their campaign in Poland in 1288. Most of the Russian records were translated by N.I. Shchaveleva ${ }^{5}$.

Further in Annals there follow the compilations from the Russian-Lithuanian Chronicles. A. Semkowicz supposed that the first examples of such compilation can be found in the entry devoted to the events of 1382 . A. Semkowicz didn't identify exactly terminus post quem of the use of Russian-Lithuanian Chronicles, but assumed it to have been in the records of $1390 s^{6}$. In historiography, terminus post quem of the compilation of RussianLithuanian Chronicles is also considered to be $1430 \mathrm{~s}^{7}$. Nevertheless, Yu. A. Limonov did not support his opinion by reliable examples, and this fact allowed the researcher of the Belarusian-Lithuanian Chronicles N. N. Ulashchik to regard Yu. A. Limonov' hypothesis as unconvincing 8 .

J. Dlugosz is associated with the beginning of a new stage in Polish historiography 9 "Annals of Poland" is one of the first works where the history of Poland is introduced into the context of world history. J. Dlugosz tried to evaluate the position of Poland on the political map of Europe. He was no longer a chronicler, but a historian and an active participant of many events described by him. J. Dlugosz wanted to show the Poles as hegemons in Eastern Europe. He claimed that the territory of Russia had been dependent on Poland from the ancient times, and had to be incorporated several times but due to different circumstances - mainly due to excessive generosity of the Polish rulers - gained temporary independence, but under the vigilant control of Poland. J. Dlugosz colorfully described the wealth of Russian lands, trying to demonstrate how serious and great the enemy of Poland was in order to glorify, ultimately, the victory of Poles. Thus, he also promoted his own state. The conceptions laid down in the Annals, considering their widespread and active use by subsequent chroniclers, for a long time determined the attitude towards Poland and its neighbors.

J. Dlugosz focused on the history of Poland. The rest served as a background for its glorification: as he pointed out, "quatenus historie nostre series crassior redderetur"10 (to present more thoroughly the course of our [i.e. Polish] history).

"Russian entries" of the Annals are devoted mainly to the southern and south-western Russia: these are either events related to the struggle for the throne of Kiev, or events in Halych or Volhynia. A special aspect for studying and analyzing is the incorrect chronology of a larger part of Russian records ${ }^{11}$.

J. Dlugosz had extremely fragmentary information about events in the north-eastern Russia. Brief information appears only in the record about 1184 . The story begins with the death of the Grand Duke of Vladimir Mikhalko Yurievich and the beginning of the reign

${ }^{5}$ Shchaveleva N.I. Drevniaia Rus'v “Pol'skoi istorii” Jana Dlugosza (knigi I-VI): Tekst, perevod, kommentarii. Moscow, 2004.

${ }^{6}$ Semkowicz A. Krytyczny rozbiór Dziejów polskich Jana Dlugosza (do roku 1384). Kraków, 1887. P.54-55.

7 See: Limonov Iu. A. Kul'turnye sviazi Rossii s Evropeiskimi stranami v XV-XVI vekakh. Leningrad, 1978; Nalivaiko R. A. O russko-litovskih istochnikah XV v. "Annales Poloniae" Jana Dlugosza // Vestnik Sankt-Peterburgskogo universiteta. Seria 2. Istoria. 2007. Iss. 3. P. 55-62.

8 Ulashchik N. N. Vvedenie v izuchenie Belorussko-litovskogo letopisaniia. Moscow, 1985. P. 82.

9 Dąbrowski J. Dawne dziejopisarstwo Polskie (do roku 1480). P. 187-188.

${ }^{10}$ Ioannis Długossii Annales seu Cronicae incliti Regni Poloniae. Lib. I-II. P. 62-63.

11 See: Nalivaiko R.A. K voprosu o hronologii russkikh izvestii “Annalov Pol'shi” Jana Dlugosza // Povest' vremennykh let: k 900-letiiu sozdaniia. Sbornik nauchnykh statei. Eds Iu. V. Krivosheev, N. V. Shtykov. St. Petersburg, 2018. P. 162-170. 
of Vsevolod in Vladimir. This entry reflects a story similar to the story in the Laurentian chronicle $6685(1177)^{12}$.

Narrating about the intestine war in the Vladimir-Suzdalian Rus' in 1216-1218 (in the Annals it is incorrectly dated 1206), J. Dlugosz mentioned the cities of Pereslavl, Vladi$\mathrm{mir}^{13}$. But he deemed them southern cities because he used the names of their princes as actors in the story of another punitive campaign of the Poles against Russia in $1211^{14}$.

In the entry under 1207, which tells about the Ryazan Prince Gleb who killed six of his relatives ${ }^{15}$, the name of the city turns into an ethnonym "rezany" - "reszani". This information of the Annals clearly goes back to the north-eastern source, and in Russian Chronicles it is dated by $6725(1217)^{16}$.

Finally, the last entry relating to north-eastern Russia taken from the Russian Chronicles is a brief reference to the attack of the Mongol-Tatars on Ryazan and Suzdal land, which J. Dlugosz dates by 1228 . The name of the murdered Prince of Ryazan is not mentioned; Prince of Vladimir is incorrectly named "Gregory"17 by J. J. Dlugosz.

Hence, in the Annals there are only occasional mentions of Suzdal, Vladimir and Ryazan borrowed from the Russian Chronicles before the Mongol invasion. The history of these lands from the second half of the $13^{\text {th }}$ century was unknown to J. Dlugosz. Lithuania had active contacts with Moscow in the $14^{\text {th }}-15^{\text {th }}$ centuries, but the Annals don't reflect these facts.

It might be hypothesized that according to the views of J. Dlugosz, he selected only the material concerned with the southern Russian lands. B. N. Florya considered that J. Dlugosz deliberately ignored the reports about the Moscow State of the second half of the $15^{\text {th }}$ century, as a rival of Lithuania ${ }^{18}$. But with this assumption, it is unclear why some of such reports were recorded in the Annals. The absence of this information is likely to be explained by the content of the Russian and Russian-Lithuanian source of Annals, where this information was absent.

J.Dlugosz considered rulers of Moscow and Tver to be Russians; he narrated about the Russian population of Veliky Novgorod and Pskov. At the same time, he regarded the king of Poland and the Grand Duke of Lithuania Kazimierz IV as the ruler of almost all Russian lands. J. Dlugosz a priori considered Novgorod and Pskov to have been dependent on Poland and Lithuania since the time of Vytautas.

The first Prince of Moscow who is mentioned in the Annals is Vasily I Dmitrievich. $\mathrm{He}$ is mentioned in connection with the activities of the Grand Duke of Lithuania Vytautas.

In the entry under 1403, J. Dlugosz tells about the conquest of Smolensk ${ }^{19}$. The last Prince of Smolensk is referred to as Vasily. This Vasily, according to Annals, fled to Hun-

12 Lavrent'evskaia letopis' // Polnoe sobranie russkikh letopisei (PSRL) Vol. I. Moscow, 1997. P. 379.

13 Shchaveleva N. I. Drevniaia Rus' v "Pol'skoi istorii” Jana Dlugosha. P. 351.

14 Ibid. P. 358.

15 Ibid. P. 352.

16 Lavrent'evskaia letopis.' P. 440-441.

17 Shchaveleva N. I. Drevniaia Rus' v "Pol'skoi istorii” Jana Dlugosza. P. 363.

18 Floria B.N. Russko-pol'skie otnosheniia i politicheskoe razvitie Vostochnoi Evropy vo vtoroi polovine XVI - nachale XVII veka. Moscow, 1978. P. 14.

${ }^{19}$ Ioannis Długossii Annales seu Cronicae incliti Regni Poloniae. Lib. X (1370-1405). Varsaviae, 1985. P. $250-251$. 
gary, where he died during the siege of some castle ${ }^{20}$. The last Prince of Smolensk was Yuri Svyatoslavich, and after the conquest of his Principality, he fled not to Hungary, but to Moscow, to Vasily Dmitrievich. J. Dlugosz either confused the Prince of Smolensk with Vasily of Moscow, or with Vasily Boreykovich, the governor appointed by Vitovt, who appeared in Smolensk, according to the Russian-Lithuanian Chronicles, after the first conquest in 1395. Vasily, who fled to Hungary, could also have been one of the boyars. After the conquest of Smolensk, Vytautas began to exert pressure on Pskov and Novgorod, which led to a war with Moscow in 1406-1408. This war is reflected in the Annals. In the entry about 1406, there is a description of the first collision; the name of the Prince of Moscow is not mentioned; the story is quite short. The case is presented as if Vytautas committed devastation with impunity, and the Prince of Moscow didn't try to resist. At the end of the campaign, Vytautas granted the Poles military banners near the Ugra river, which, according to J. Dlugosz, was the main river of the "Muscovite land" (terra Mosquitarum) ${ }^{21}$. J. Dlugosz says nothing about the reasons for Vytautas's attack on Moscow lands.

The second campaign of Vytautas to Moscow is described by J. Dlugosz under $1408^{22}$. This report contains more details; here J. Dlugosz introduces the name of Prince Vasily, and underlines that he is the son-in-law of Vytautas married to his daughter, whom J. Dlugosz calls Anastasia ${ }^{23}$, and it is not a misprint as under 1412 the wife of Vasily of Moscow again is named Anastasia ${ }^{24}$. Commentators of the Annals (in a separate edition and in the comments in the latest edition) consider that there is a mistake ${ }^{25}$. However, it is possible that Annals are the only source, where the Catholic name of Sofia is indicated. At the same time, J.Dlugosz mentions Prince Vasily and his wife, but says nothing about the fact of their marriage.

Details of the war are not specified. When Vytautas approached the river Oka, the legates of Vasily of Moscow arrived, and peace was concluded. J. Dlugosz vividly describes the calamity caused by constant rains and mud in the woods ${ }^{26}$ - all these details are usually attributed to the memoirs of some Pole, a participant of this campaign ${ }^{27}$ by the commentators of Annals. The Polish army returned to king Wladyslaw on St. Martin's day - November 11. Dating of this war in Annals - from June to November - is also confirmed by Russian sources: the Nikon Chronicle narrates that Vasily went to Vytautas on September 1, 6917 (1408), and that there were "Poles, Germans and Samogitians"28 in the army of Vytautas, which completely tallies with the information of J. Dlugosz. But, according to Russian sources, the peace was concluded not on the Oka, but on the Ugra river.

${ }^{20}$ Ibid. P. 251.

${ }^{21}$ Ioannis Długossii Annales seu Cronicae incliti Regni Poloniae. Varsaviae, 1997. Lib. X-XI (1406-1412). P. 14.

22 Ibid.P. 19-21.

23 Ibid. P. 19.

24 Ibid. P. 212.

${ }^{25}$ Rozbiór krytyczny Annalium Poloniae Jana Długosza z lat 1385-1444. Vol. I. Wrocław; Warszawa; Kraków, 1961. P.77; Ioannis Długossii Annales seu Cronicae incliti Regni Poloniae. Lib. X-XI (1406-1412). P. 221.

26 Ibid. P. 20-21.

27 Rozbiór krytyczny Annalium Poloniae Jana Długosza z lat 1385-1444. Vol. I. P. 77-78.

${ }^{28}$ Letopisnyi sbornik, imenuemyi Patriarshei ili Nikonovskoi letopis'iu // PSRL. Vol.XII. Moscow, 2000. P.205. 
The next news relating to north-eastern Russia is the entry under 1426 about the war of Vytautas with Pskov ${ }^{29}$. The information is given without any connections to previous events. J.Dlugosz considers the reluctance of Pskov to establish borders in accordance with Vytautas's desires to be the reason for the war. Vytautas besieged the castle Voronets, which is rated as the second in importance among nine castles of the Pskov lands. Here Vytautas faced bad weather - for 5 weeks it rained constantly. Due to these circumstances, he offered peace, but Pskov, considering it a weakness, refused. At this time the rain stopped, and Pskov was easily defeated, after which a peace, beneficial to Vytautas, was concluded, and the siege of Voronets castle was ended ${ }^{30}$. The reference to this war can be found in the "Kroinika Litovskaya i Zhmoytskaya", where under 1427 the siege of the castle of Sebezh, and then the siege of Porkhov are described. According to "Kroinika", Pskov gave up and began to pay tribute of 5000 chervonets $^{31}$. J. Dlugosz doesn't mention either Sebezh or Porkhov, and there is no indication of the amount of tribute. At the same time, very precise details are included in the Pskov and Novgorod Chronicles. The Pskov Chronicles describing the war with Vytautas in 1426, narrate about the siege of Opochka, then - of Voronach, under which Vytautas stood for three weeks ${ }^{32}$, not five, as J.Dlugosz tells, whereas the Annals don't mention the siege of Opochka. The Pskov Chronicles (I and II) narrate that there was bad weather during the siege of Voronach because of which Vytautas was forced to make peace; that Pskov didn't accept it, but was defeated; that under Voronach peace was concluded with Vytautas ${ }^{33} \mathrm{~J}$. Dlugosz also colorfully describes the bad weather. In general, his story is similar to The Pskov Chronicles' narrative, but less detailed. Nikon Chronicle ${ }^{34}$ and Voskresenskaya Chronicle ${ }^{35}$ also bear resemblance to the Pskov Chronicles telling about bad weather during the siege of Voronach, and the reception of 3000 rubles by Vytautas. Similarity to the Annals can also be seen in the Novgorod Fourth Chronicle, where under 1426 it is said about the war with Pskov and Vytautas, and the seizure of Voronach. It is indicated that Vytautas gained 1000 rubles from Pskov ${ }^{36}$. Likewise, the Sophia Second Chronicle contains an analogous story ${ }^{37}$. The information of J.Dlugosz is closest to the Pskov Chronicles.

Under 1428, J.Dlugosz narrates about the war between Vytautas and Novgorod ${ }^{38}$. According to the Annals, the Novgorodians looked upon Vytautas with derision, considering that their city, surrounded by swamps, ponds and lakes could not be taken. Vytautas crossed the Black forest, and besieged Opochka which was guarded by three thousand warriors. An embassy of Novgorodians was sent to Vytautas: a Bishop and 14 noblemen. The peace was concluded in the vicinity of Opochka. As a tribute, Vytautas received 10 thousand of silver rubles, 50 sable coats and many other coats and 30 purple shrouds ${ }^{39}$.

${ }^{29}$ Joannis Dlugossii Annales seu Chronicae incliti regni Poloniae. Varsaviae, 2000. Lib. XI (14131430). P. 219-220.

30 Ibid.

31 Khroniki: Litovskaia i zhmoitskaia, i Bykhovca // PSRL. Vol. XXXII. Moscow, 1975. P.79-80.

32 Pskovskie letopisi // PSRL. Vol. V, iss. 1. Moscow, 2003. P. 35-36; Ibid. Iss. 2. Moscow, 2000. P. 121122.

33 Ibid. Vol. V, iss. 1. P. 36; Ibid. Vol. V, iss. 2. P. 122.

${ }^{34}$ Letopisnyi sbornik, imenuemyi Patriarshei ili Nikonovskoi letopis’yu // PSRL. Vol. XII. P.7.

35 Prodolzhenie letopisi po Voskresenskomu spisku // PSRL. Vol. VIII. Moscow, 2001. P. 93-94.

${ }^{36}$ Novgorodskaia chetvertaia letopis' // PSRL. Vol. IV, iss. 1. Moscow, 2000. P. 432.

37 Sofiiskaia vtoraia letopis.'// PSRL. Vol. VI, iss. 2. Moscow, 2001. P. 51.

38 Joannis Dlugossii Annales seu Chronicae incliti regni Poloniae. Lib. XI (1413-1430). P.243-246.

39 Ibid. P. 245. 
J. Dlugosz narrates about the siege of Opochka, while in the actual fact Vytautas besieged Porkhov during that campaign. The mentioning of Opochka suggests that J.Dlugosz could transfer a number of episodes of the Pskov campaign to Novgorodian. "Kroinika Litovskaya i Zhmoytskaya" reports that the Novgorodians after this campaign had to pay annually to Vytautas 10 thousand "golden czervonets" and also skins of sable, marten, lynx, fox, ermine, squirrel. ${ }^{40}$ The Novgorod First Chronicle mentions the Embassy to Vytautas: "archbishop Euthymius... with the ambassadors Novgorodians"41.

The mention of paid tribute brings us to another detail - the "courageous" passage of Vytautas' troops through a "Black forest" (Czarnylasz) ${ }^{42}$ which had to be overcome in order to approach Novgorod. Later Polish chroniclers as, for example, M. Kromer ${ }^{43}$, or M. Stryjkowsky ${ }^{44}$ do not narrate about any "black forest". Only M. Belsky tells about some large forests ${ }^{45}$. The term "chernjy bor" is reflected in this "Black forest" - an extraordinary tax collected by the Grand Prince of Moscow in the Novgorod lands. However, two decades after Vytautas, Novgorodians granted Casimir IV the right to collect "chernjy bor" from some Novgorodian lands ${ }^{46}$. It is clear that J. Dlugosz didn't understand a specific term and wrote about forest - in Russian "bor" means "forest".

Vytautas by the end of his reign had reached the apogee of his power. He was the guardian of his grandson Vasily II of Moscow, his authority was recognized by the princes of north-eastern Russia, Novgorod, and Pskov. Nevertheless, this sphere of activity of $\mathrm{Vy}$ tautas, except for his relations with Novgorod and Pskov, remained completely unknown to J. Dlugosz.

The next Grand Prince of Moscow, whose activities are mentioned in the Annals Vasily II Vasilyevich, but J. Dlugosz never indicates his name and doesn't mention that he is the grandson of Grand Duke Vytautas.

The first mention is connected with the Congress in Wilno in 1430 arranged by Vytautas on the eve of the coronation, which eventually didn't take place. The Princes of Moscow, Tver, Odoev, Masters of the Crusaders and the Tatar Emperor arrived in Wilno, as J. Dlugosz points out ${ }^{47}$.

\section{J. Dlugosz doesn't indicate the name of the Prince of Moscow.}

The second mention is a story related to the Council in Ferrara and Florence, in which Isidore, Metropolitan of Kiev, took part. This Council confirmed the Church Union. J.Dlugosz narrates about the Union, mentions the presence of Isidore at the Council ${ }^{48}$, and in the entry under 1440 tells about his return. In Poland, as J. Dlugosz writes, Isidore was met benevolently, whereas the reaction was different in Moscow, where Isidore was captured, imprisoned and kept until "by the grace of God" he managed to escape ${ }^{49}$. Nar-

${ }^{40}$ Khroniki: Litovskaia i zhmojtskaia, i Byhovca // PSRL. Vol. XXXII. P. 80.

${ }^{41}$ Novgorodskaia pervaia letopis' starshego i mladshego izvodov // PSRL. Vol. III. Moscow, 2000. P. 415 .

42 Joannis Dlugossii Annales seu Chronicae incliti regni Poloniae. Lib. XI (1413-1430). P. 243.

${ }_{43}$ Kromer M. Kronika Polska. Sanok, 1857. P. 874-875.

44 Stryjkowski M. Kronika Polska, Litewska, Żmódska i wszystkiéj Rusi. Cracoviae, 1582. P. 558-559.

45 Bielsky M. Kronika Polska. Sanok, 1856. P. 590.

${ }^{46}$ Cherepnin L. V. Obrazovanie Russkogo tsentralizovannogo gosudarstva v XIV-XV vekakh. Ocherki social'no-ekonomicheskoii politicheskoi istorii Rusi. Moscow, 1960. P.771.

47 Joannis Dlugossii Annales seu Chronicae incliti regni Poloniae. Lib. XI (1413-1430). P. 285-286.

48 Ioannis Długossii Annales seu Cronicae incliti Regni Poloniae. Varsoviae, 2001. Lib. XI-XII (14311444). P. 207-208.

49 Ibid. P. 221. 
rating about this event, as well as about the Congress in Lutsk, J. Dlugosz doesn't mention the name of the Prince of Moscow and even uses plural form: "principes Moschouie".

In the record under 1448, J. Dlugosz again mentions rulers of north-eastern Russia. He narrates that at the beginning of the year, ambassadors from the Princes of Moscow, Novgorod-Seversky, Tatar Emperor and ambassadors of Veliky Novgorod, "communitas Novogrodensis" 50 , arrived to congratulate Casimir on his coronation. J. Dlugosz again omits the name of the Prince of Moscow.

Under this same 1448, the event, also connected with north-eastern affairs is casually mentioned. In September 1448, when Casimir was in Grodno, he sent the army formed from Lithuanians and Samogitians against the Prince of Tver, who besieged some "royal castle" 51 . J. Dlugosz doesn't give the details of this event. In fact it was Rzhev, which was captured by the Lithuanians in February 1448, where Prince Boris Alexandrovich hardly escaped capturing. In 1448, Tver troops tried to reconquer this fortress, and in autumn Casimir sent troops to Rzhev where the temporary peace was concluded ${ }^{52}$. This event is also confirmed by Tver sources ${ }^{53}$. E. Klug in his monography dedicated to the history of the Principality of Tver tried to find out where Grate Duke Casimir in the autumn of 1448 was. It is evident that J. Dlugosz provides this information.

The latest plot in which Vasily II is mentioned, and again without being called by name, is an account of the death of Mikhail Sigismundovich in 1452 in Moscow ${ }^{54}$. First J. Dlugosz claims that Mikhail was poisoned by the order of the Prince of Moscow. The poison was so strong that it destroyed his skull ${ }^{55}$. However, further J. Dlugosz, contradicting his earlier words, tells that some Lithuanians were suspected of Mikhail's murder ${ }^{56}$. The Annals are not the only source which narrates about the poisoning of Mikhail. The same information is given in the Bychoviec Chronicle, albeit with other details - the poisoner is identified as a certain Abbot who did not like Michael so much that he gave him poison, whereupon, being frightened, took this poison himself ${ }^{57}$.

Thus, there is no direct evidence of the involvement of Vasily II in the death of Mikhail in the sources. J. Dlugosz writes about the negative attitude of the Lithuanian nobility to Mikhail Sigismundovich; he even notes that in Lithuania there were those who rejoiced in the death of Mikhail and were suspected of poisoning him ${ }^{58}$. Nevertheless, commentators of Annals assert that Michael was poisoned by a dyak Stephen Borodaty by the order of Vasily $\mathrm{II}^{59}$, the same information is given in the "Polish dictionary of biography" in the article written by S. Kuczynski dedicated to Mikhail Sigismundovich ${ }^{60}$. Stefan Borodaty is mentioned as a poisoner in two Chronicles: Ermolinskaya ${ }^{61}$ and Lvovskaya ${ }^{62}$, but in these

\footnotetext{
50 Ioannis Długossii Annales seu Cronicae incliti Regni Poloniae. Lib. XII (1445-1461). P. 59.

51 Ibid. P.71.

52 Kliug E. Kniazhestvo Tverskoe (1247-1485). Tver', 1994. P. 307.

53 Rogozhskii letopisec. Tverskoi sbornik // PSRL. Vol. XV. Moscow, 2000. P. 494.

54 Ibid. P. 124-25.

55 Ioannis Długossii Annales seu Cronicae incliti Regni Poloniae. Lib. XII (1445-1461). P. 124.

56 Ibid. P. 125.

57 Khroniki: Litovskaia i zhmojtskaia, i Byhovca // PSRL. Vol. XXXII. P. 159-160.

58 Ioannis Długossii Annales seu Cronicae incliti Regni Poloniae. Lib. XII (1445-1461). P. 125.

59 Ibid. P. 418.

60 Polski Słownik Biograficzny. Wrocław; Warszawa; Kraków; Gdańsk, 1975. Vol. XX/3, zeszyt 86.

61 Ermolinskaia letopis' // PSRL. Vol. XXIII. Moscow, 2004. P. 155.

62 L'vovskaia letopis' // PSRL. Vol. XX. Moscow, 2005. P. 262.
} P. 610. 
Chronicles he is called the poisoner of Dmitry Shemyaka. Shemyaka died in Novgorod at about the same time with Mikhail. Rumors about poisoning of Shemyaka could have been associated with another event connected with Mikhail Sigismundovich, and in this form appeared in the Russian-Lithuanian Chronicle, where neither the place nor the time of death of Michael is named, similarly to the Annals.

J. Dlugosz wrote nothing about Casimir's relations with Moscow when Lithuania supported Dmitry Shemayaka, and Moscow supported Mikhail Sigizmundovich. The main attention of J.Dlugosz was focused on Western affairs: relations with the Crusaders, the Empire. The Eastern affairs, obviously, were of little interest to him. Thus, in the record about Simeon Olelkovich's death under 1471, J.Dlugosz tells that at the time he was the Governor of Casimir in Novgorod ${ }^{63}$. But why he was there, and what Casimir needed from Novgorod, is not indicated.

New brief mentioning of the Prince of Moscow can be found in the entry of 1474, again without his name. It is told there that in February ambassadors from Venice arrived to Casimir, one of whom - Antony - went to Moscow. J. Dlugosz vaguely notes that the Pope had some deals with the Prince of Moscow ${ }^{64}$. A. L. Khoroshkevich clarifies that this ambassador was Antonio Gislardi who arrived in Moscow in July 1474 three months after the meeting with Casimir ${ }^{65}$.

Finally, one of the last entries of the Annals dated by 1479 gives an account of Moscow affairs. J. Dlugosz narrates that Casimir IV reconciled with the Moscow Princes and list their names: "natu maiori Iwano et Borzivogio Andree et altero Andrea" ${ }^{66}$. In this "Borzivoy" one can see either the misunderstood nickname of Andrei the elder - "Big Goryai", or, more likely, the misspelled name of Boris (in the Krakow edition of the Annals (1873-1878) the name is given as "Boguworio" $\left.{ }^{37}\right)$. The dispute between Casimir and the Princes of Moscow, as J.Dlugosz points out, was about some lands of the Grand Duchy of Lithuania, which "Moschouienses" captured ${ }^{68}$. Commentators of Annals suppose that these were the claims of Ivan III to Kiev, and the possibility of creating an anti-Turkish coalition ${ }^{69}$. According to another assumption, these were territorial disputes after annexation of Novgorod by Moscow ${ }^{70}$. A. A. Zimin suggested that it was about so-called "Rzhev tribute" - the cities of Rzhev, Velikie Luki and Toropets, which were in dual subordination, and "Rzhev tribute" came to the ruler of Lithuania"

And further in the same report J. Dlugosz narrates about Ivan III, telling that he overthrew the Tatar yoke, under which Moscow had been oppressed since the time of Vytau$\operatorname{tas}^{72}$. As the researchers notice, J.Dlugosz was the first who described this dependence

${ }^{63}$ Ioannis Długossii Annales seu Cronicae incliti Regni Poloniae. Lib. XII (1462-1480). P. 263.

64 Ibid. P. 327.

${ }^{65}$ Khoroshkevich A.L. Moskovskoe gosudarstvo v sisteme mezhdunarodnykh otnoshenii kontsa XV — nachala XVI v. Moscow, 1980. P. 187.

${ }^{66}$ Ioannis Długossii Annales seu Cronicae incliti Regni Poloniae. Lib. XII (1462-1480). P. 442.

67 Joannis Długossii seu Longini canonici cracoviensis Historiae Polonicae libri XII / ed. by A. Przezdziecki. Cracoviae, 1878. Vol. V. P. 697.

${ }^{68}$ Ioannis Długossii Annales seu Cronicae incliti Regni Poloniae. Lib. XII (1462-1480). P. 442.

69 Ibid. P. 391.

70 Borisov N. S. Ivan III. Moscow, 2000. P. 471.

71 Zimin A.A. Rossiia na rubezhe XV-XV stoletii: (ocherki sotsial'no-politicheskoi istorii). Moscow, 1982. P.95.

72 Ibid. P. 442 
by the word "jugum": "jugum barbaricum", "jugum servitutis"73. In the Annals, there is a story about the humiliation of the Princes of Moscow who met the Tatar ambassadors on foot, threw expensive fur coats under their feet and were forced to fight against the Catholics at the will of the $\mathrm{Khan}^{74}$. A similar story is found in "Kroinika Litovskaya $\mathrm{i}$ Zhmoytskaya" ${ }^{25}$, in the Polish Chroniclers of the $16^{\text {th }}$ century, but they are secondary to J. Dlugosz's record.

It is important to note the chronological framework that J.Dlugosz set out for the Mongol yoke: from the beginning of the reign of Vytautas until $1479^{76}$. Since J. Dlugosz didn't use the north-eastern Russian Chronicles, and the southern Russian Chronicles ended with the entries about the events of 1238, he could not link the Mongol attack on Russian lands with the establishment of the yoke. Particularly noteworthy is the indication of J. Dlugosz that by the beginning of 1480 the Tatar yoke had already been thrown off. J. Dlugosz died in May 1480, before "the Great stand" on the Ugra river. However, he considered Moscow to be free. A.A. Gorsky, referring to J. Dlugosz, suggested that the Tatar yoke had not existed already in 1472, after the unsuccessful campaign of Akhmad in Aleksin ${ }^{77}$.

Further, J. Dlugosz writes about the establishment of control over Novgorod, and stipulates that this was done because of the neglect of Casimir, to whom Novgorod annually paid 100 thousand rubles ${ }^{78}$. The Annals narrate that Ivan beheaded 300 chief inhabitants in Novgorod $^{79}$. However, in January 1478, when Novgorod capitulated, no executions were carried out ${ }^{80}$. Executions were conducted in the late $1479-$ early $1480^{81}$. This fact is mentioned by V.N. Tatishchev, according to whose story more than 100 people were executed $^{82}$. Thus J. Dlugosz's records reflected not the conquest of Novgorod in 1478, but the pacification of the Novgorod rebellion two years later. That was why J. Dlugozs accused Casimir IV who didn't help those who asked him.

Dlugosz summed up his story with the phrase claiming that thanks to the treasures taken in Novgorod, Ivan became terrible to his neighbors, occupied some regions of Lithuania and began to threaten everyone in the neighborhood ${ }^{83}$. There is another remarkable detail in this story - Lithuanians, according to J. Dlugosz, were going to resist Moscow, but Casimir constantly dissuaded them saying that the Orthodox population would sympathize with Moscow, and therefore it was better for Lithuanians to wait for the help of Poles $^{84}$. However, as further events showed, when the wars between Moscow and Lithu-

${ }^{73}$ Gorskij A. A. Russkoe srednevekov'e. Moscow, 2010. P. 183.

${ }^{74}$ Ioannis Długossii Annales seu Cronicae incliti Regni Poloniae. Lib. XII (1462-1480). P. 442-443.

75 Hroniki: Litovskaya i zhmojtskaya, i Byhovca. PSRL. Vol. XXXII. P. 92.

${ }^{76}$ Nalivaiko R.A. Russko-ordynskie otnosheniia XIII-XV vv. v "Annalakh Pol'shi” Jana Dlugosha // Drevniaia Rus' vo vremeni, v lichnostiakh, v ideiakh. Materialy nauchnoi konferentsii "Prepodobnyi Sergii Radonezhskii: lichnost' v kontekste epokhi i istoriia ego pochitaniia", Sankt-Peterburg, 1-3 oktiabria 2014 g. St. Petersburg; Kazan', 2015. P. 46-57.

77 Gorskij A. A. Moskva i Orda. Moscow, 2001. P. 133-134.

78 Ioannis Długossii Annales seu Cronicae incliti Regni Poloniae. Lib. XII (1462-1480). P. 443.

79 Ibid.

80 Alekseev Yu. G. "K Moskve khotim": Zakat boiarskoi respubliki v Novgorode. Leningrad, 1991.

81 Borisov N. S. Ivan III. P. 291.

82 Tatishchev V.N. Sobranie sochinenii: in 8 vols. Reprint s izd. 1965-1966. Moscow, 1996. Vol. V, VI. Istoriia Rossiiskaia. Ch. 3, 4. P. 68.

${ }^{83}$ Ioannis Długossii Annales seu Cronicae incliti Regni Poloniae. Lib. XII (1462-1480). P. 443-444.

${ }^{84}$ Ibid. 
ania began, first for the Upper Oka Principalities, then for the Chernigov-Seversky land and Smolensk, Lithuania did not get effective assistance from the Poles, and eventually lost a significant part of the Russian lands.

J.Dlugosz created his Annals at a time when the main attention of Poland and the Grand Duchy of Lithuania were turned to the West. The Thirteen Years' war with the Teutonic Order had just ended successfully; Casimir IV took an active part in the struggle for power in Central Europe, actively participated in the Crimean and Tatar affairs, maintained relations with Wallachia and Moldavia.

Eastern affairs related to the powerful Moscow Principality were still on the periphery of attention. That is why the internal affairs of Moscow didn't interest the Polish chroniclers. J. Dlugosz intended to describe the history of those lands that became part of Poland and the Grand Duchy of Lithuania and successfully coped with this, making use of the Russian Chronicles. But these sources narrated about southern and south-western Russia. In the Annals there are no detailed records about Polotsk or Turov-Pinsk lands, only fragmentary information. A similar situation concerns Vladimir-Suzdal Principality and further history of these lands. J. Dlugosz doesn't mention Moscow Princes of the $14^{\text {th }}$ century, and any events of this time. Even regarding the $15^{\text {th }}$ century only those events which are directly associated either with Lithuania or with Poland can be found there. All this is clear enough - at the time of J. Dlugosz, Moscow was not yet a serious threat, so its internal history was still irrelevant.

And at the same time, it is significant that one of the last entry of the Annals is devoted to activity of Ivan III: J. Dlugosz writes about it rather respectfully, notes rapid strengthening of his position and points out that in the future all this will threaten both Lithuania and Poland.

\section{References}

Alekseev Yu. G. "We Want to Moscow". The Decline of Boyar Republic in Novgorod. Leningrad, Lenizdat Publ., 1991, 158 p. (In Russian)

Borisov N. S. Ivan III. Moscow, Molodaia Gvardiia Publ., 2000, 644 p. (In Russian)

Cherepnin L.V. Formation of the Russian Centralized State in $14^{\text {th }}-15^{\text {th }}$ Centuries. Essays on the SocioEconomic and Political History of Russia. Moscow, 1960, 900 p. (In Russian)

Dąbrowski J. Dawne Dziejopisarstwo Polske (do roku 1480). Wrocław; Warszawa; Kraków, Wydawnictwo Polskiej Akademii Nauk, 1964, 267 p.

Floria B.N. Russian-Polish Relations and Political Development of Eastern Europe in the Second Half of the $16^{\text {th }}-$ early $17^{\text {th }}$ century. Moscow, Nauka Publ., 1978, 302 p. (In Russian)

Gorskij A. A. Moscow and the Horde. Moscow, Nauka Publ., 2001, 214 p. (In Russian)

Gorskij A. A. Russian Medieval Period. Moscow, Astrel' Publ., Olimp Publ. 2010, 222 p. (In Russian)

Khoroshkevich A.L. Moscow State in the System of International Relations of the late $15^{\text {th }}-$ early $16^{\text {th }}$ Centuries. Moscow, Nauka Publ., 1980, 294 p. (In Russian)

Kliug E. The Principality of Tver. Tver', Tver' Publ., 1994, 432 p. (In Russian)

Limonov Yu. A. Cul'tural Relations of Russia with the European Countries in the $15^{\text {th }}-16^{\text {th }}$ Centuries. Leningrad, Nauka Publ., 1978, 272 p. (In Russian)

Nalivaiko R.A. On the Chronology of Russian Reports of "Annals of Poland" by Jan Dlugosz. "Povest' Vremennyh let": k 900-letiyu sozdaniia. Sbornik nauchnykh statei. Eds Yu. V. Krivosheev, N. V. Shtykov. St. Petersburg, Izdatel'stvo Olega Abyshko Publ., 2018, pp. 162-170. (In Russian)

Nalivaiko R. A. On the Russian-Lithuanian Sources of the $15^{\text {th }}$ Century in "Annales Poloniae" by Jan Dlugosz. Vestnik of Saint Petersburg University. History, 2007, iss. 3, pp. 55-62. (In Russian)

Nalivaiko R. A. Russian-Horde Relations in the $13^{\text {th }}-15^{\text {th }}$ Centuries in "Annals of Poland" by Jan Dlugosz. Drevniaia Rus' vo vremeni, $v$ lichnostiakh, $v$ ideiakh. Materialy nauchnoi konferentsii "Prepodobnyi 
Sergii Radonezhskii: lichnost' v kontekste epokhi i istoriia ego pochitaniia", Sankt-Peterburg, 1-3 oktiabria 2014 g., St. Petersburg, Kazan', 2015, pp. 46-57. (In Russian)

Semkowicz A. Krytyczny rozbiór Dziejów polskich Jana Dlugosza (do roku 1384). Kraków, 1887, 408 p.

Semkowicz-Zarembina W. Powstanie i dzieje autografu Annalium Jana Długosza. Krakow, Wydawnictwo Polskiej Akademii Nauk, 1952, 87 p.

Shchaveleva N. I. Ancient Rus in "Polish History" by Jan Dlugosz (books I-VI): Text, Translation, Commentary. Moscow, Pamiatniki istoricheskoi mysli Publ., 2004, 210 p. (In Russian)

Ulashchik N. N. Introduction to the Study of the Belarusian-Lithuanian Chronicles. Moscow, Nauka Publ., 1985, 264 p. (In Russian)

Zimin A. A. Russia at the turn of 15-16 $6^{\text {th }}$ Centuries: (Essays on Socio-Political History). Moscow, Mysl' Publ., 1982, 333 p. (In Russian)

Статья поступила в редакцию 24 июля 2019 г.

Рекомендована в печать 2 декабря 2019 г.

Received: July 24, 2019

Accepted: December 2, 2019 